\title{
Волшебные помощники в калмыцком и тувинском эпосе"
}



В статье анализируются архаические корни калмыцкого эпоса «Джангар» на материале песни «О Хара Кинесе», входящей в него, а также тувинского сказания «Хунан-Кара». Предметом анализа выступила категория волшебных помощников - чудесных способностей эпических героев, а также помощников-людей, животных и пр. персонажей, помогающих им.

Сравнительно-сопоставительный анализ песни «О Хара Кинесе» раннего Багацохуровского циикла калмыцкого эпоса с тувинским сказанием «Хунан-Кара» подтверждает, что песнь основана на ядерных архачческих образованиях предшествовавших эпических систем. Эпосы выделяют на первый план персонифицированные способности героев, нежели конкретных волшебных помощников. Герои обладают свойством превращаться в паршивого мальчишку, владеют волшебными предметами. Все они восходят к архаическому обряду инициации.

Ключевые слова: калмыцкий эпос; Джангар; тувинский эпос; Хунан-Кара; сказочный мотив; волшебный помощник

"Исследование проведено в рамках государственной субсидии - проект «Устное и письменное наследие монгольских народов России, Монголии и Китая: трансграничные традиции и взаимодействия» (регистрационный номер АААA-А19-119011490036-1).

Убушиева Д. В. Волшебные помощники в калмыцком и тувинском эпосе [Электронный ресурс] // Новые исследования Тувы. 2019, № 4. URL: https://nit.tuva.asia/nit/article/view/892 (дата обращения: дд.мм.гг.). DOI: 10.25178/ nit.2019.4.14

Убушиева Данара Владимировна - кандидат филологических наук, старший научный сотрудник отдела монгольской филологии Калмыцкого научного центра Российской академии наук. Адрес: 358000, Россия, г. Элиста, ул. им. И. К. Илишкина, д 8. Тел.: + 7 (84722) 3-55-06. Эл. адрес: bib.danara@yandex.ru ORCID ID: 0000-0002-5547-4006

Ubushieva Danara Vladimirovna, Candidate of Philology, Senior Research Associate, Department of Mongolian Philology, Kalmyk Scientific Center of the Russian Academy of Sciences. Postal address: 8 Ilishkin St., 358000 Elista, Russian Federation. Tel.: +7 (84722) 3-55-06. E-mail: bib.danara@yandex.ru 


\title{
Magic assistants in the Kalmyk and Tuvan epics"
}

\author{
Danara V. Ubushieva \\ Kalmyk Scientific Center of the Russian Academy of Sciences, Russian Federation
}

The article analyzes archaic roots of the Kalmyk epic of Jangar traced in the Song of Khara Kines (included in the latter) and the Tuvan legend of Khunan Kara. The paper examines the category of magic assistants - miraculous skills of the epic characters and ones in the forms of humans, animals and other helpful characters.

The comparative analysis of the Song of Khara Kines included in the early Baga Tsokhor Cycle of the Kalmyka epic and the Tuvan legend of Khunan-Kara concludes the former is actually based on nuclear archaic elements of preceding epic systems. The epic sets forth personified skills of its characters rather than those of magic assistants. The epic characters can turn into lousy boys and possess magic attributes, which mirrors the archaic initiation rituals.

Keywords: Kalmyk epic; Jangar; Tuvan epic; Khunan-Kara; fairy-tale motif; magic assistant

\footnotetext{
"The reported study was funded by government subsidy - project name 'Oral and Written Heritage of the Mongolic Peoples of Russia, Mongolia and China: Cross-Border Traditions and Interactions’' registration number AAAA-A19-119011490036-1).
}

\section{For citation:}

Ubushieva D. V. Magic assistants in the Kalmyk and Tuvan epics. The New Research of Tuva. 2019, № 4. URL: https://nit. tuva.asia/nit/article/view/892 (access date ...). DOI: 10.25178/nit.2019.4.14

\section{Введение}

Для понимания процесса сложения сюжета героического эпоса, определения времени формирования его основного ядра - важно изучить внутреннюю структуру сюжета и определить доминирующую роль тех или иных компонентов в процессе изображения событий, происходящих в эпосе. В отечественном эпосоведении устоялось мнение относительно калмыцкого эпоса «Джангар», как произведения героического типа.

Нами предпринята попытка изучения эволюции эпоса «Джангар», а именно его ранних циклов Багацохуровского 1853 г. и Малодербетовского 1862 г. для обнаружения более древней эпической системы, трансформация которой образовала настоящие рассматриваемые циклы. В предыдущих наших работах выявлена двенадцати элементная структура «тууль-улигерного» (архаического) эпоса в двух ранних циклах калмыцкого «Джангара» (Убушиева, 2019а). Также был проведен сравнительнотипологический анализ темы богатырское сватовство, сохранившейся в песнях Багацохуровского цикла «Джангара» со сказаниями о сватовстве алтайцев, бурят и тувинцев, который выявил, что песни цикла основаны на инвариантных ядерных мотивах архаического эпоса, как и эпос тюрко-монгольских народов Сибири (Убушиева, 2019b).

В настоящей работе мы продолжим выявление архаических корней эпоса «Джангар» на материале песни «О Хара Кинесе» раннего Багацохуровского цикла (1853 г.). Обнаружение древних элементов эпоса требует сравнительно-типологических исследований с другими архаическими эпическими системами. Как замечено Б. Н. Путиловым, «в рамках одной этнической традиции осуществить реконструкцию предшествующего состояния не представляется возможным <...> единственный про- 
дуктивный путь - подключение сравнительных материалов» (Путилов, 2003: 175). В этой связи нами проведен анализ категории «волшебные помощники» в песнях «О Хара Кинесе» ${ }^{1}$ калмыцкого «Джангара» и тувинского сказания «Хунан-Кара» (Тувинские героические сказания, 1997). Отобранные песни относятся к архаическому типу, что прослеживается в их разложимости по биографическим звеньям или «тууль-улигерной» структуре (Кичиков, 1997; Орус-оол, 2018).

В.Я. Пропп под категорией волшебный помощник понимает чудесные способности героев и владение волшебными предметами (Пропп, 2004). «Рассмотрение помощника неотделимо от рассмотрения волшебных предметов. Они действуют совершенно одинаково» (там же: 139), также отмечено, что «... в сказке помощник может рассматриваться как персонифицированная способность героя» (там же: 139). При преломлении данной теории к эпическим повествованиям, обнаруживается, что «персонифицированные способности героя» выходят на первый план, а функции помощников и волшебных предметов носят второстепенный характер, но не маловажный. Таким образом, чудесные способности эпических героев и их окружения как перевоплощение, способность исцелять/воскрешать и владение различными атрибутами - это и есть один из видов категории волшебного помощника, по Проппу.

Тема волшебных помощников достаточно подробно изучена в системе персонажей сказочного фольклора. В эпических же системах данная категория мало исследована, рассмотрены прямые проекции данного персонажа - помощник-конь, помощник-птица, помощник-табунщик. Нами предпринята попытка преломления категории «волшебный помощник» в эпосе в свете теории В. Я. Проппа. Рассмотрение этих свойств эпических героев раскрывает глубоко архаические коды этносов и обнаруживает универсальные элементы эпических систем.

\section{Обзор научной литературы}

Бытование сказаний о «Джангаре» среди тувинцев стало известно в 1960-е гг. Тувинским исследователем Д. С. Куулар в 1957 г. было записано сказание «Богдо Чангар хаан» ('Хан Богдо Чангар') от сказителя Баян Узуновича Балбыр (1881-1962). В комментариях к публикации отмечено, что «Названную сказку запомнил по рассказу другого сказителя по имени Дөңгур-Хемчик. Отсюда становится понятным, что сказку в Тоджу, т. е. на восток Тувы привез человек с запада, из района, граничащего с Алтаем, теленгитами» (Куулар, 1973: 122). Так же отмечено иноязычное происхождение имени Чангар от калмыцкого Жаңһр ('Джангар') (там же). Перевод данного сказания на русский язык осуществлен также Д. С. Куулар и опубликован в 1973 г. в «Ученых записках НИИЯЛИ» (Куулар, 1973). Автор записи и перевода заключает: «... сказание “Богдо Чангар хан” стоит особняком в списке тувинских эпических произведений, отличаясь от них стилем повествования, фабулой, “географией”, атрибутикой героического, ономастикой и топонимией» (Куулар, 2004: 143). Об этом же сказании писал А. Ш. Кичиков, который указал на общие мотивы, характерные для общемонгольской эпической традиции, а также на существенные различия, как в композиционном построении сказания, так и в сюжетном наполнении произведения (Кичиков, 1973).

Бытованию эпоса «Джангар» в фольклоре алтайских тувинцев посвящена работа Э. Таубе (Таубе, 2004), в которой также не обошлось без параллелей с калмыцким эпосом. Исследовательнице не удалось записать сказание о «Джангаре», но информантами засвидетельствовано бытование рассказов о Джангаре, имевших ритуальные функции (там же: 172). Также параллели обнаружены и в сказочном фонде калмыков и тувинцев (там же: 173-174), отмечены варианты сказок на один мотив «L81B. Отсеченные ноги героя. Спутники героя оставляют саблю, меч и т. п. перед входом в его шатер (комнату). Когда герой в спешке выбегает наружу, лезвие ранит его (обычно отсекает ноги)» (Березкин, Дувакин, Электр. ресурс).

С. М. Орус-оол рассмотрела параллели калмыцкого эпоса «Джангар» с эпическими сказаниями тувинцев, алтайцев, хакасов, шорцев и бурят. Параллели обнаружены как в мотивах и персонажах сказочно-мифологического пласта эпоса, так и в поэтике. Эти сходства исследователь объясняет «... древними, не прерывающимися культурно-историческим контактами, общностью исторических судеб. Духовная жизнь этих народов развивалась на базе сходных поверий, общих религиозных

\footnotetext{
${ }^{1}$ Olon bum burxan üde dumduni üdelegsen... (Сотни тысяч бурханов в полдень пребывают в покое...) // Рукописный отдел Библиотеки Восточного факультета Санкт-Петербургского государственного университета. Calm. С. 17. Ед. хр. 1770. Л. 1-28. Строки 30-31. (Рукопись на ойратском языке).
} 
воззрений: шаманизма и ламаизма (тувинцы, буряты, калмыки), что и предопределило общность традиций и обычаев, морально-этических норм» (Орус-оол, 2011: 43-44).

Волшебные помощники на материале русской сказки подробно исследованы В. Я. Проппом (Пропп, 2004). На материале восточнославянской сказки образы помощников рассмотрены Н. В. Новиковым (Новиков, 1974). Помощники главного героя в адыгских сказках изучены А. И. Алиевой (Алиева, 1986).

В калмыцкой фольклористике данная категория исследована как в сказочной, так и в эпической традиции. М. Э. Джимгировым в калмыцкой волшебной сказке выделены следующие помощники: благодарная птица, чудесный предмет, зверь-помощник, чудесный конь, быстрорастущее дерево и коса прекрасной девушки (Джимгиров, 1970: 36). И. С. Надбитовой выделены основные образы помощников героя в калмыцкой волшебной сказке. Исследователь относит к ним: людей (ханская дочь, жена/супруга, суженая, сестра героя, мать героя, пастух, табунщик, лама, почтенный старик, сановник, слуги хана, старушка); мифологических персонажей (Белый старец); чудесных искусников (передвигающий горы, переливающий воду океана, ловящий сайгаков, слухач, меткий стрелок и невидимка); животных (конь, птица Хан-Гаруди); загробных помощников (покойные родители, благодарный мертвец) (Надбитова, 2011: 128-143). Б. Б. Горяевой рассмотрены волшебные помощники в соответствии с классификацией В. Я. Проппа. Она выделила три категории помощников: 1) универсальные (выполняющие все пять функций): конь; 2) частичные (выполняющие менее пяти функций): Хан-Гаруди; 3) специфические помощники (исполняющие только одну из пяти функций): ковёр, меч, яблоко и др. (Горяева, 2017). Так же Б. Б. Горяевой выявлены и описаны орнитоморфные помощники в калмыцкой волшебной сказке, к ним отнесены: мифическая птица Хан-Гаруди, орёл, сорока, ворона, петушок, воробей, курица, уточка, попугай (Горяева, 2018). С. В. Мирзаевой проведен сравнительный анализ сюжетов о чудесном помощнике в сказках калмыков России и ойратов Западной Монголии, который выявил семь типов чудесных помощников в калмыцких сказках и два типа в сказках ойратов (Мирзаева, 2015).

На эпическом материале монгольских народов мотив помощника героя изучен Э. Б. Оваловым. Он сделал вывод, что в процессе эволюции эпических систем образ помощника героя имел следующую трансформацию: «зооморфные существа в бурятском эпосе, малолетние герои в монгольской версии “Джангара”, богатыри в ойратском эпосе, наконец “нулевой цикл” в калмыцком эпосе» (Овалов, 1982: 56).

А. Ш. Кичиковым обозначены помощники-заячи в тууль-улигерном (архаическом) эпосе. К ним отнесены конь, духи предков в образах старика или старухи, а также табунщик Ак-Сахал. «В наиболее архаических повествованиях Ак-Сахалу соответствует “белый старец” (Кичиков, 1997: 49), который «... в глубокой древности мог иметь общее тюркское и монгольское прозвище “Белобородый”, “Белая борода” <...> Постепенно в представлениях об Ак-Сахале стала доминировать земная, человеческая ипостась <...> “Земной” Ак-Сахал, эволюционировав, выступал то в роли дядюшки героя, то в ролях воспитателя, наставника, старшего табунщика, наконец, просто табунщика-раба (в зависимости от стадиального уровня эпического сказания)» (Кичиков, 1997: 49).

В тувинской фольклористике сказочный фонд так же всесторонне изучен. И. А. Вчерашней в диссертация «Тувинские народные сказки» рассмотрены характеристика тувинских сказок, тематика содержания, художественно-поэтические приемы тувинской сказки (Вчерашняя, 1955). Д. С. Кууларом проведена жанровая классификация сказок и их сюжетных типов (Куулар, 1976, 2000). Э. Таубе о тувинских волшебных сказках пишет следующее: «Они являются наиболее древними литературными свидетельствами и, возможно, уходят своими корнями во времена первобытной общности. По своей мировоззренческой основе и по сюжетному содержанию к ним очень близки богатырские сказки, в центре которых героические походы и приключения богатыря с целью завоевать невесту или восстановить нарушенный врагом порядок» (Сказки и предания алтайских тувинцев, 1994: 26). В 1994 г. был издан том «Тувинские народные сказки» (Тувинские народные сказки, 1994) в серии «Памятники фольклора народов Сибири и Дальнего Востока». В данное издание вошли восемь лучших образцов тувинской волшебной сказки, а так же обозначены волшебные помощники: «...золотая дангына, мать, сестра героя, белобородый старец, старик-телятник, бедная женщина, добрый хан, а также богатырский конь, птица Хан-Херети (Гаруда), черный ворон, золотой орел, божественный ястреб с лошадиной головой, золотая рыбка, змея и другие благодарные животные, рыбы, птицы» (там же: 19-20) помогающие главному герою (сироте, пасынку, обездоленному и др.). Герои волшебных сказок используют и волшебные предметы: шапку-невидимку, идики-скороходы, деревянную колотушку, шелковые разноцветные хадаки, обломки точильного камня, гребня и прочее. Следует отметить, что исследователями выделяются и обозначаются волшебные помощники и предметы в тувинском фольклоре, но специальных исследований по ним мы не обнаружили. 


\section{Персонифицированные способности героев}

Персонифицированной способностью героя в эпосе является свойство перевоплощения.

В тувинском эпосе «Хунан-Кара» им обладают:

- сам богатырь Хунан-Кара:

Хунан-Кара,

Пользуясь тысячью волшебствами,

Пользуясь тысячью колдовствами (Тувинские героические сказания, 1997: 269);

- его мать Сай-Тоюн-ханша:

Принимающая сто восемь обликов

[Его] мать Сай-Тоюн-ханша (там же: 95);

- его суженая Узун-Назын-дангына:

Узун-Назын-дангына

Тысячу обликов принимающая,

Тысячью волшебствами-колдовствами обладающая (там же: 211);

- его тесть Узун-Сарыг-хан:

Узун-Сарыг-хан

Черного барана-трехлетку забил,

Целиком его тушу зажарил,

В [шарик] наподобие бабки[-кости]

Заклинанием превратил

И волшебством-колдовством

Демир-моге

Им покормил (там же: 221-223);

- Демир-моге - соперник Хунан-Кара в сватовстве за суженую:

Я же, когда он будет писать

Белыми чертами письмо,

Тучи белые пригоню,

И если буду метать до полудня

Белые молнии ... (там же: 177 ).

В калмыцкой песне «О Хара Кинесе» персонифицированными способностями обладают:

- Джангар-хан:

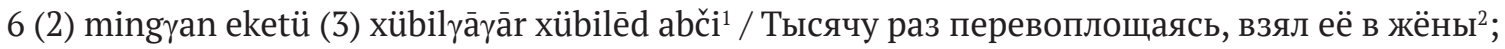

- богатырь Алтан Чеджи ${ }^{3}$ :

6 (4) irēd ügei yeren yesün ǰilīgi ömönösöni aildaǰi mededeq: öng- (5) görād odoqsan zūn jilīgi martal

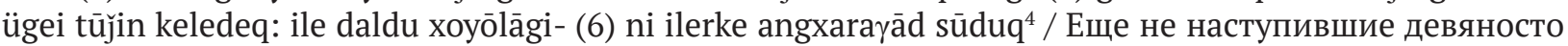
девять лет наперед знает, О прошедших ста годах не забывая пересказывает, Об открытом и скрытом повествуя, сидит;

- богатырь Хонгор 5 :

21 (18) aqčim zūr arban xoyor xübildaq / В мгновение двенадцать раз перевоплощаюсь.

Относительно супруги Джангар-хана Ава Герезел в тексте нет прямого описания ее перевоплощений, но априори подразумевается, что она также имеет данные способности, выраженные тем, что она

\footnotetext{
${ }^{1}$ Olon bum burxan üde dumduni üdelegsen... С. 6 .

2 Здесь и далее перевод наш. - Д. У.

${ }^{3}$ Предсказатель, ясновидец, богатырь Джангар-хана во время пира возглавляет правую сторону богатырей.

${ }^{4}$ Olon bum burxan üde dumduni üdelegsen... C. 6 .

${ }^{5}$ Первый богатырь Джангар-хана во время пира возглавляет левую сторону богатырей.

${ }^{6}$ Olon bum burxan üde dumduni üdelegsen... C. 21.
} 


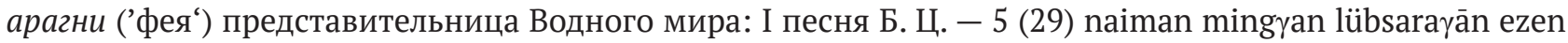
güši zamba xāni küken ${ }^{1}$ / Хозяина восьми тысяч лубсурга, Гюши Замба хана дочь.

Внутри данного ряда персонифицированных свойств можно выделить свойство, которым обладают только главные эпические персонажи - это превращение в паршивого мальчишку:

Своего Арзылан-Кара

В паршивого черного

Стригунка обратил -

Вот-вот он помрет.

А сам Хунан-Кара

Плохоньким стал,

В желтом войлочном хевенеке,

На чепраке из барсучьей шкуры,

Со стременами из деревяшек

Еле-еле он затрусил (Тувинские героические сказания, 1997: 249);

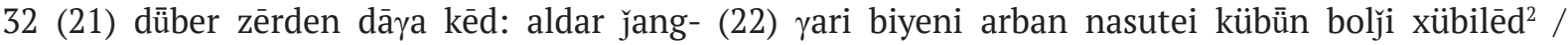
Гордого Зерде в жеребёнка-двухлетку превратил, / Сам славный Джангар, обернулся десятилетним мальчиком.

В рассматриваемых текстах перевоплощение героя в паршивого мальчишку связано с проникновением Хунан-Кара в ставку антагониста Кара-Когел-хана, который пленил его родителей, а Джангар-хана - в кузницу к дархану ('кузнецу') Кёке.

С. Ю. Неклюдов связывает превращение героя в паршивого мальчишку с обрядом инициации, как «переходный этап между небытием и бытием человека» (Неклюдов, 2019: 97), которое соответствует матримониальному сюжету, где «... облик и статус героя трансформируется по схеме жизнь - смерть возрождение» (там же). В рассматриваемых образцах превращение героя в паршивого мальчишку не имеет связи с матримониальными коллизиями, но сама ситуация является кульминационной для эпического повествования.

\section{Волшебные предметы}

В песне «О Хара Кинесе» калмыцкого эпоса к персонифицированному свойству главного героя относится его умение исцелять/воскрешать. Джангар-хан исцеляет, как одного богатыря, к примеру, Савара:

33 (23) zū šagmunīn arabmalaqsan zokistu sayixan emiyigi: šara tor šaba xoyor dēreni asaxād: aqčimiyin düdūdü edegegēd aba ${ }^{3}$ / Священным Шакьямуни освященное, подходящее прекрасное снадобье, из складок жёлтого шёлкового платья достав, Посыпал на раны и увечья, и в мгновение исцелил.

Так он исцеляет и целое войско богатырей:

36 (18) ezen dēdü boqdoni erdeni biligiyin xuriyigi (19) eqce dolōn xonoqtu orūlād: emne edegēkü

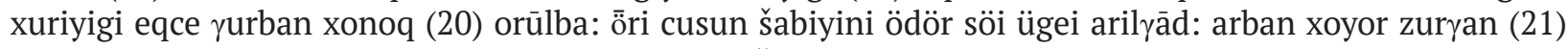


adi tidlen adislaba: amidü čindamanīn adi tidiyigi (23) adistidlēd edegēgēd aba / Владыка, верховный богдо / Драгоценный благодатный дождь / Вызвал на семь суток / Исцеляющий дождь, вызвал на трое суток. / Днем и ночью избавлял от гноя, крови и раны / Двенадцать и шесть тысяч богатырей / Словно живых собрал и усадил, / Благодетельными бурханами благословлённым / Священным белым талисманом освятив, / Живым чиндамани освятив, благословив исцелил.

Разница обнаруживается в предмете, которым Джангар-хан пользуется при исцелении. В случае исцеления одного богатыря используется снадобье, которое засыпается тому в рот и нос. При исцелении

${ }^{1}$ Olon bum burxan üde dumduni üdelegsen... C. 5

${ }^{2}$ Olon bum burxan üde dumduni üdelegsen...C. 32 .

${ }^{3}$ Olon bum burxan üde dumduni üdelegsen...C. 33 .

${ }^{4}$ Olon bum burxan üde dumduni üdelegsen...C. 36 . 
же целого войска проводится ритуал призывания дождя и освящение богатырей исцеляющим чиндамани (драгоценным камнем). Присутствие религиозного компонента (освящение снадобья божеством) является поздним напластованием, корни же обряда глубоко сказочные и относятся к волшебным предметам. Снадобье, равно как и мазь, по Проппу, относится к категории волшебных предметов: «... при посвящении юноши получали власть над животными и внешним выражением этого было то, что им давалась часть этого животного» (Пропп, 2004: 162). Если в сказке речь идет о волосках, зубах и прочем, то в эпосе средства трансформировались в снадобья и камни.

В данном отношении тувинский эпос «Хунан-Кара» сохранил прямой пример. Здесь богатырей кормят шариками из мяса животных (снадобьем), чьи силы затем они приобретают. Тесть ХунанКара - Узун-Сарыг-хан и суженая Хунан-Кара - Узун-Назын-дангына совершают равно одинаковые обряды, заключающиеся в ритуальном умерщвлении и приготовлении черного барана трехлетки и черного быка трехлетки соответственно. Затем оба превращают их в шарики и скармливают УзунСарыг-хан - Демиру-моге, а Узун-Назын-дангына - Хунан-Кара. Демир-моге обретает силу черного барана трехлетки, а Хунан-Кара - черного быка трехлетки. И они продолжают поединок.

Каждый день

Прибавлялась, оказывается

У Демир-Моге сила,

Равная силе

Черного барана-трехлетки (Тувинские героические сказания, 1997: 224);

Каждый день

Стала прибавляться, оказывается,

У Хунан-Кара сила,

Равная силе

Черного быка-трехлетки (там же: 225).

Мы говорим тем самым о волшебных предметах в арсенале героя-богатыря. В. Я. Проппом выделены основные группы таких предметов: «предметы животного происхождения, растительного происхождения, предметы, в основе которых лежат орудия, предметы многообразного состава, которым приписываются или самостоятельные или персонифицированные силы, и, наконец, предметы, связанные с культом мертвых» (Пропп, 2004: 170).

Из приведенного выше примера, мы видим, что Джангар-хан владеет волшебным камнем и снадобьем, восходящим к обрядам инициации. В тувинском эпосе Хунан-Кара владеет предметами, которые в категории волшебных предметов, относятся к более поздним звеньям, это книга-судур и шелковый платок:

[Была у него] трехсаженная

Желтая [книга-]судур

С четырехугольным черным

Каптазыном [из пластинок] камня -

Про три злосчастья

Из нее узнают (Тувинские героические сказания, 1997: 57);

[Хунан-Кара] на черном утесе

Шелковый черный материнский олбук

[Под] себя положил,

Шелковый платок,

В шесть раз длинней своей ширины,

В шесть слоев сложил,

На макушку себе положил (там же: 187).

Несмотря на то, что волшебные предметы, используемые богатырями тувинского и калмыцкого эпоса, различного происхождения, они, как и волшебные помощники, берут свое начало в древнем обряде инициации. 


\section{Заключение}

Волшебные помощники отражают сказочные мотивы эпоса, в то же время, они «... не остаются в эпосе неизменными: они трансформируются, приспосабливаясь к новому пониманию возможного и правдоподобного» (Жирмунский, 1958: 28).

Сопоставление показало, что эпос выделяет персонифицированные способности героев, нежели конкретных волшебных помощников. Главные эпические герои рассмотренных эпических образцов обладают свойством превращаться в паршивого мальчишку, образ которого берет начало в обряде инициации. Относительно волшебных предметов, выявленных в эпических текстах, следует отметить, что все они в более или менее трансформированном виде так же восходят к архаическому обряду инициации. Сравнительно-сопоставительный анализ песни «О Хара Кинесе» раннего Багацохуровского цикла калмыцкого эпоса с тувинским сказанием «Хунан-Кара» подтверждает, что песнь основана на ядерных архаических образованиях предшествовавших эпических систем. В целом же волшебные помощники принадлежат к той обязательной сюжетной категории, которые оказывают движущую силу сюжетно-мотивных звеньев и являются универсалиям, как сказочных, так и эпических систем.

\section{СПИСОК ЛИТЕРАТУРЫ}

Алиева, А. И. (1986) Поэтика и стиль волшебных сказок адыгских народов. М. : Наука. 280 с.

Березкин, Ю.Е., Дувакин, Е. Н. Тематическая классификация и распределение фольклорно-мифологических мотивов по ареалам. Аналитический каталог [Электронный ресурс] // Фольклор и постфольклор: структура, типология, семиотика. URL: https://ruthenia.ru/folklore/berezkin/ (дата обращения: 20.10.2019).

Вчерашняя, И. А. (1955) Тувинские народные сказки : автореф. дис.... кандидата филол. наук. М. 16 с.

Горяева, Б. Б. (2017) Орнитоморфные помощники героя в калмыцкой волшебной сказке // Известия Волгоградского государственного педагогического университета. № 9 (122). С. 134-141.

Горяева, Б. Б. (2018) Мотив волшебного помощника в калмыцкой сказке // Проблемы этнической истории и культуры тюрко-монгольских народов. № 5. 76-85. DOI: 10.22162/2500-1531-2018-5-76-85

Джимгиров, М. Э. (1970) О калмыцких народных сказках. Элиста : Калмыцкое книжное издательство. 103 с.

Жирмунский, В. М. (1958) Эпическое творчество славянских народов и проблемы сравнительного изучения эпоса. М. : Издательство академии наук СССР. 146 с.

Кичиков, А. Ш. (1973) О тувинской богатырской сказке «Богда Чангар хаане» // Ученые записки. Вып. ХІ. Серия Филологии. Элиста : Республиканская типография управления по делам издательств полиграфии и книжной торговли Совета Министров Калмыцкой АССР. 238 с. С. 118-121.

Кичиков, А. Ш. (1997) Героический эпос «Джангар». Сравнительно-типологическое исследование памятника. М. : Восточная литература. 320 с.

Куулар, Д. С. (1973) Богдо Чангар хан (тувинский эпос) // Ученые записки. Вып. ХІ. Серия Филологии. Элиста : Республиканская типография управления по делам издательств полиграфии и книжной торговли Совета Министров Калмыцкой АССР. 238 с. С. 122-127.

Куулар, Д. С. (1976) Сказки // Очерки тувинского фольклора / отв. ред. А. К. Калзан. Кызыл : Тувин. кн. изд-во. 183 с. С. $44-65$.

Куулар, Д. С. (2000) Тувинский фольклор в контексте центрально-азиатских устно-поэтических традиций : автореф. дис. ... д-ра филол. наук в форме науч. докл. Улан-Удэ. 46 с.

Куулар, Д. С. (2004) Тувинская версия «Джангара» // «Джангар» и проблемы эпического творчества. Материалы Международной научной конференции (22-24 августа 1990 года) / отв. ред. Э.Б. Овалов. Элиста : АПП «Джангар». 542 с. С. 143-148.

Мирзаева, С. В. (2015) Сюжеты о чудесном помощнике в сказочном фольклоре калмыков и ойратов Западной Монголии // Проблемы этнической истории и культуры тюрко-монгольских народов. № 3. C. $186-195$.

Надбитова, И. С. (2011) Сюжеты, образы и стилевые традиции калмыцких волшебных сказок. Элиста : ЗАОр «НПП «Джангар». 260 с. 
Неклюдов, С. Ю. (2019) Фольклорный ландшафт Монголии. Эпос книжный и устный. М. : Индрик. 592 c.

Новиков, Н. В. (1974) Образы восточнославянской волшебной сказки. Л. : Наука. 255 с.

Овалов, Э. Б. (1982) Мотив «помощник героя» в версиях эпоса «Джангар» // Эпическая поэзия монгольских народов / отв. ред. Н. Ц. Биткеев. Элиста : КНИИИФЭ. 158 с. С. 50-56.

Орус-оол, С. М. (2011) «Джангар» и эпос тюрко-монгольских народов // Орус-оол, С. М. Избранные научные труды. Абакан : ООО «Журналист». 295 с. С. 35-44.

Орус-оол, С. М. (2018) Сходные сюжеты и мотивы эпоса тюрко- монгольских народов Сибири и огузского эпоса «Книга моего деда коркута» // Алтай - Западная Сибирь в XIX - начале XX вв.: население, хозяйство, культура. Материалы Всероссийской научно-практической конференции, посвященной 160-летию со дня рождения этнографа, экономиста и общественного деятеля Сергея Порфирьевича Швецова / отв. ред. Н. В. Екеев Горно-Алтайск : Бюджетное научное учреждение Республики Алтай «Научно-исследовательский институт алтаистики им. С. С. Суразакова». 356 с. С. 330-340.

Пропп, В. Я. (2004) Исторические корни волшебной сказки. М. : Лабиринт. 332 с.

Путилов, Б. Н. (2003) Фольклор и народная культура; In memoriam. СПб. : Петербургское востоковедение. 464 с.

Сказки и предания алтайских тувинцев (1994) / сост. Э. Таубе. М. : «Восточная литература» РАН. 410 с.

Таубе, Э. (2004) Следы сюжетов «Джангара» в фольклоре тувинцев на Алтае // «Джангар» и проблемы эпического творчества. Материалы Международной научной конференции (22-24 августа 1990 года) / отв. ред. Э. Б. Овалов. Элиста : АПП «Джангар». 542 с. С. 172-189.

Тувинские народные сказки (1994) / сост. З. Б. Самдан. Новосибирск : Наука, Сибирская издательская фирма. 460 с.

Тувинские героические сказания (1997) / сост. С. М. Орус-оол. Новосибирск : Наука. 584 с.

Убушиева, Д. В. (2019а) Мотивы «тууль-улигера» (архаического эпоса) в героическом эпосе «Джангар» // Новый филологический вестник. № 1 (48). С. 57-69. DOI: 10.24411/2072-9316-2019-00004

Убушиева, Д. В. (2019b) Матримониальные коллизии в калмыцком эпосе «Джангар» и сказаниях тюрко-монгольских народов Сибири // Oriental Studies. № 4. С. 707-715. DOI: 10.22162/2619-0990-201944-4-707-715

Дата поступления: 30.08.2019 2.

\section{REFERENCES}

Alieva, A. I. (1986) Poetika i stil' volshebnykh skazok adygskikh narodov [Poetics and style of magic fairy tales of the Adyghe peoples]. Moscow, Nauka. 280 p. (In Russ.).

Berezkin, Yu.E.and Duvakin,E.N.Tematicheskaya klassifikatsiyai iraspredeleniefol'klorno-mifologicheskikh motivov po arealam. Analiticheskii katalog [Thematic classification and territorial distribution of folklorerelated mythological motifs. Analytical catalog]. In: Fol'klor i postfol'klor: struktura, tipologiia, semiotika [Folklore and Post-Folklore: Structure, Typology and Semiotics]. [online] Available at: URL: https://ruthenia.ru/ folklore/berezkin/ (access data: 20.10.2019). (In Russ.).

Vcherashniaya, I. A. (1955) Tuvinskie narodnye skazki [Tuvan folk tales]. Cand. of Philology thesis abstract. Moscow. 16 p. (In Russ.).

Goryaeva,B.B.(2017) Ornitomorfnye pomoshchniki geroia v kalmytskoi volshebnoi skazke [Ornithomorphic assistants of a character in the Kalmyk fairy tale]. Izvestiya of the Volgograd State Pedagogical University, no. 9 (122), pp. 134-141. (In Russ.).

Goryaeva, B. B. (2018) Motiv volshebnogo pomoshchnika v kalmytskoi skazke [Motif of the magic assistant in the Kalmyk fairy tale]. Problemy etnicheskoi istorii i kul'tury tyurko-mongol'skikh narodov, no. 5, pp. 76-85. (In Russ.). DOI: 10.22162/2500-1531-2018-5-76-85

Dzhimgirov, M. E. (1970) O kalmytskikh narodnykh skazkakh [About Kalmyk folk tales]. Elista, Kalmyk Book Publ. 103 p. (In Russ.).

Zhirmunsky, V. M. (1958) Epicheskoe tvorchestvo slavianskikh narodov i problemy sravnitel'nogo izucheniia eposa [Epic creativity of the Slavic peoples and problem of comparative studies of the epic]. Moscow, USSR Academy of Sciences. 146 p. (In Russ.). 
Kichikov, A. Sh. (1973) O tuvinskoi bogatyrskoi skazke «Bogdo Changar khane» [About the Tuvan heroic tale ‘Bogda Chagar-Khan’]. In: Uchenye zapiski. Elista, KNIIYaLI. Is. XI. 238 p. Pp. 118-121. (In Russ.).

Kichikov, A. Sh. (1997) Geroicheskii epos «Dzhangar». Sravnitel'no-tipologicheskoe issledovanie pamiatnika [The heroic epic of Jangar. A comparative-and-typological study of the monument]. Moscow, Vostochnaya Literatura. 320 p. (In Russ.).

Kuular, D. S. (1973) Bogda Changgar khan (Tuvinskii epos) [Bogda Changgar khan (a Tuvan epic)]. In: Uchenye zapiski. Vol. XI. Elista, KNIIYaLI. 238 p. Pp. 122-127. (In Russ.).

Kuular, D. S. (1976) Skazki [Tales]. In: Ocherki tuvinskogo fol'klora [Essays on Tuvan folklore]. Kyzyl, Tuvan Book Publ. 183 p. Pp. 44-65. (In Tuv.).

Kuular, D. S. (2000) Tuvinskii fol'klor v kontekste tsentral'no-aziatskikh ustno-poeticheskikh traditsii [Tuvan folklore in the context of Central Asian oral poetic traditions]. Doctor of Philology thesis abstract. Ulan-Ude. 46 p. (In Russ.).

Kuular, D. S. (2004) Tuvinskaia versiia «Dzhangara» [A Tuvan version of the Jangar]. In: Dzhangar» i problemy epicheskogo tvorchestva [The Jangar and problems of epic creativity]. Proceedings of the International scientific conference (August 22-24, 1990). Ed. by E. B. Ovalov. Elista, Dzhangar. 542 p. Pp. 143-148. (In Russ.).

Mirzaeva, S. V. (2015) Syuzhety o chudesnom pomoshchnike v skazochnom fol'klore kalmykov i oiratov Zapadnoi Mongolii [Plots about a magic assistant in fabulous folklore of the Kalmyks and Oirats of Western Mongolia]. Problemy etnicheskoi istorii i kul'tury tyurko-mongol'skikh narodov, no, 3, pp. 186-195. (In Russ.).

Nadbitova, I. S. (2011) Syuzhety, obrazy i stilevye traditsii kalmytskikh volshebnykh skazok [Plots, images and stylistic traditions of Kalmyk magic tales]. Elista, Dzhangar. 260 p. (In Russ.).

Neklyudov, S. Yu. (2019) Fol'klornyi landshaft Mongolii. Epos knizhnyi i ustnyi [The folklore landscape of Mongolia. The epic: bookish and oral ones]. Moscow, Indrik. 592 p. (In Russ.).

Novikov, N. V. (1974) Obrazy vostochnoslavianskoi volshebnoi skazki [Images of the East Slavic magic fairy tale]. Leningrad, Nauka. 255 p. (In Russ.).

Ovalov, E. B. (1982) Motiv «pomoshchnik geroia» v versiiakh eposa «Dzhangar» [Motif of the 'hero's assistant' in versions of the Jangar epic]. In: Epicheskaia poeziia mongol'skikh narodov [Epic poetry of Mongolic poples]. Ed. by N. Ts. Bitkeev. Elista, KNIIIFE. 158 p. Pp. 50-56. (In Russ.).

Orus-ool, S. M. (2011) «Dzhangar» i epos tiurko-mongol'skikh narodov [The Jangar and the TurkoMongolian epic]. In: Orus-ool, S. M. Izbrannye nauchnye Trudy [Selected works]. Abakan, Zhurnalist. 295 p. Pp. 35-44. (In Russ.).

Orus-ool, S. M. (2018) Skhodnye siuzhety i motivy eposa tiurko- mongol'skikh narodov Sibiri i oguzskogo eposa «Kniga moego deda korkuta» [The epic of Siberian Turko-Mongols and the Oguz epic 'Book of Dede Korkut']. In: Altai - Zapadnaia Sibir' v XIX - nachale XX vv.: naselenie, khoziaistvo, kul'tura [Altai - Western Siberia in the late $19^{\text {th }}$ - early $20^{\text {th }} c c$.: population, economy, culture]. Proceedings of the research and practice conference commemorating the $160^{\text {th }}$ anniversary of birth of the ethnographer, economist and social activist Sergei P. Shvetsov. Ed. by N. V. Ekeev. Gorno-Altaisk, Suzarakov Research Institute for Altaic Studies. 356 p. Pp. 330-340. (In Russ.).

Propp, V. Ia. (2004) Istoricheskie korni volshebnoi skazki [Historical roots of the magic tale]. Moscow, Labirint. 332 p. (In Russ.).

Putilov, B. N. (2003) Fol'klor i narodnaia kul'tura; In memoriam [Folklore and national culture; In memoriam]. St. Petersburg, Peterburgskoe Vostokovedenie. 464 p. (In Russ.).

Skazki i predaniia altaiskikh tuvintsev [Fairy tales and legends of the Altaian Tuvans] (1994). Comp. by E. Taube. Moscow, Vostochnaya Literatura. 410 p. (In Russ.).

Taube, E. (2004) Sledy syuzhetov «Dzhangara» v fol'klore tuvintsev na Altae [Traces of the Jangar's plots in folklore of Altaian Tuvans]. In: Dzhangar» i problemy epicheskogo tvorchestva [The Jangar and problems of epic creativity]. Conference proceedings (Elista; August 22-24, 1990). Ed. by E. B. Ovalov. Elista, Dzhangar. 542 p. Pp. 172-189. (In Russ.). Russ.).

Tuvinskie narodnye skazki [Tuvan folk tales] (1994). Comp. by Z. B. Samdan. Novosibirsk, Nauka. 460 p. (In

Tuvinskie geroicheskie skazaniia [Tuvan heroic tales] (1997). Comp. by S. M. Orus-ool. Novosibirsk, Nauka. 584 p. (In Russ.). 
Ubushieva, D. V. (2019a) Motivy «tuul'-uligera» (arkhaicheskogo eposa) v geroicheskom epose «Dzhangar» [Motives of "Tuul-Uliger" (Archaic Epos) in the Heroic Epos "Dzhangar"]. The New Philological Bulletin, no. 1 (48), pp. 57-69. (In Russ.). DOI: 10.24411/2072-9316-2019-00004

Ubushieva, D. V. (2019b) Matrimonial'nye kollizii v kalmytskom epose «Dzhangar» i skazaniiakh tiurkomongol'skikh narodov Sibiri [Matrimonial collisions in the Kalmyk epic of Jangar and legends of Siberia's Turko-Mongols]. Oriental Studies, no. 4, pp. 707-715. (In Russ.). DOI: 10.22162/2619-0990-2019-44-4-707-715 